\title{
Iowan women farmers' perspectives on alternative agriculture and gender
}

\author{
Andrea L. Rissing ${ }^{\text {a }}$ \\ Grinnell College
}

Submitted August 9, 2012 / Revised October 2 and December 2, 2012 / Accepted December 10, 2012 /

Published online March 19, 2013

Citation: Rissing, A. L. (2013). Iowan women farmers' perspectives on alternative agriculture and gender. Journal of

Agriculture, Food Systems, and Community Development, 3(2), 127-136. http://dx.doi.org/10.5304/jafscd.2013.032.008

Copyright (C) 2013 by New Leaf Associates, Inc.

\begin{abstract}
After decades of being seen as "farm wives," an increasing number of women in American agriculture are actively farming and claiming the "farmer" identity. Previous research has demonstrated that women farmers face unique challenges and that women in the alternative agriculture movement value different elements of agricultural work than their male counterparts. This ethnographic study of 11 women farmers in Iowa's alternative agriculture movement seeks to address how these women understand the relationship between their gender and their work. The majority of the women interviewed feel that their gender influences their general farming perspective, but significantly fewer believe their gender affects their
\end{abstract}

a Andrea L. Rissing is now a doctoral student at the Department of Anthropology, Emory University, 207 Anthropology Building, 1557 Dickey Drive, Atlanta, Georgia 30322 USA; andrea.rissing@emory.edu

Note: The original research for this project was conducted while the author was an undergraduate student at Grinnell College. approach to farm sustainability. Interviewees pointed to women's problem-solving skills, concerns with health and family, and intuitive relationships to the earth as ways in which their gender impacts their general farming perspective. Interviewees were more likely to indicate their education, coworkers, or participation in farm organizations as influential in shaping their farm's sustainability. In distinguishing between these two areas, women farmers selectively engage and reproduce culturally gendered traits when positioning themselves within alternative agriculture.

\section{Keywords}

agriculture, women farmers, gender, sustainability

\section{Background and Introduction}

Women's work on farms in the United States was largely undocumented and undervalued until recently (Allen \& Sachs, 2007; Sachs, 1983). In the nineteenth century, rural agriculture moved from a subsistence system to a market-based one. Under the new system, row crops like corn - tradition- 
ally considered within the male sphere of rural labor - became more economically valuable. Despite the fact that egg and dairy money generated by women was often a household's most dependable income, the higher profit potential of row crops contributed to the social devaluing of female labor (Sachs, 1983). Later, the effects of modernization brought new technological efficiency for the farm and the home. However, while greater efficiency in men's fieldwork translated directly into profits, domestic technologies aimed at farm women were primarily labor-saving (Jellison, 1993). Women's domestic and farm labor often became "encompassed" (in the sense of Wardlow, 2006) by the men in their family. In the twentieth century, the Smith-Lever Act of 1914 structuralized the division of labor by dividing extension services into distinct categories for farm work and housework (Jellison, 1993). This expectation that farm women work inside the home continued throughout the twentieth century, becoming a marker of status for middle-class farm families and influencing public perception of what women on farms do.

Today the number of women who choose farming as their primary profession is increasing significantly. According to the 2007 Census of Agriculture, 30.2 percent of all U.S. farm operators were women (U.S. Department of Agriculture [USDA] National Agricultural Statistics Service, n.d.). This represents an increase of 19 percent from 2002, compared with the overall increase in farmers of just 7 percent (USDA, n.d.). The trend becomes even more marked among women who are principal farm operators, defined by the USDA as the person in charge of the day-to-day decision making for the farm or ranch. In 2007, women were the principal operators on 14 percent of the country's 2.2 million farms, an increase of almost 30 percent from 2002 (USDA, n.d.). Just over 1 million American women were farm operators in 2007, and 306,209 women were principal farm operators (USDA, n.d.).

However, as striking as these increases are, the word "farmer" continues, in many contemporary circles, to be primarily associated with men. This gendering of the label "farmer" affects the identities of many farm women. Recent studies indicate that women on farms, even those actively involved in the farm's operation, will often refer to themselves as "not really farmers" or "farm helpers" in lieu of "farmers" (Ferrell, 2012; Peter, Bell, Jarnagin, \& Bauer, 2006). The cultural perception that women on farms are not "farmers" contributes to the distinct challenges American women farmers face today. Foremost among these challenges is the pervasive feeling among women farmers that they are not taken as seriously as their male counterparts (Barbercheck, Brasier, Kiernan, Sachs, Trauger, Findeis, Stone, \& Moist, 2009; Bauman, 2012; Trauger, Sachs, Barbercheck, Brasier, \& Kiernan, 2010; Trauger, Sachs, Barbercheck, Kiernan, Brasier, \& Findeis, 2008). For some women farmers, this feeling can manifest in difficulty in securing loans or financial support for their farms (Bauman, 2012; Trauger et al., 2010).

In this ethnographic study, several of my informants echoed these difficulties, and further mentioned the ergonomic challenges they confronted when using farm equipment designed for male bodies. Trauger (2004) found that women farmers often prefer to farm sustainably in part because alternative agricultural communities are more likely than conventional agriculture to encourage and empower these women's identities as farmers. Within sustainable agriculture, women farmers often conceptualize their work differently than their male peers. In their well-known study, Beus and Dunlap (1990) define the paradigms of alternative and conventional agriculture, ultimately identifying decentralization, independence, community, harmony with nature, diversity, and restraint as the six primary dimensions of the alternative agriculture paradigm. When Chiappe and Flora (1998) interviewed women farmers in Minnesota, they found that the women validated the alternative agriculture paradigm, but added two more dimensions: quality family life and spirituality. Redefining what agricultural success means for them, Pennsylvanian women farmers who are engaged in civic agriculture today emphasize values such as education, fostering community, and healthy foods as essential elements of a successful farm in addition to economic profitability (Trauger et al., 2010). Additionally, a majority of women farmers interviewed in Trauger's study saw explicit 
connections between their gender and agricultural choices (Trauger et al., 2010). As members of sustainable agriculture circles, these women often have broader goals for their work and their farms than simply growing food for profit.

International studies reveal significant overlap in the gendered experiences of farmers across western industrialized countries, and studies on gender and farming frequently reference international sources (Brandth, 1994; Brandth \& Haugen, 1997; Pini, 2005). Pini (2005) and Brandth (1994) address some of the gender management strategies women farmers use to negotiate the tension between maintaining a feminine gender identity while participating in a workplace traditionally considered masculine. Norwegian women farmers employ various methods to avoid transferring "vital masculine qualities" to themselves after becoming proficient tractor operators, which is symbolically masculine work (Brandth, 1994). These methods include leaving certain areas of farm technology, such as repair, to men, and emphasizing personal and household neatness (Brandth, 1994). For Pini's (2005) Australian subjects, similar gender management strategies included minimizing their farm contributions, preferentially emphasizing their domestic work, and distancing themselves from male farmers.

While my original study did not set out to pursue questions of gender management strategies, the argument presented in this paper is rooted in the same general theoretical framework as Pini and Brandth. A social constructivist understanding of gender is used to frame the ways women farmers conceptualize their gendered identities alongside their professional identities. Agriculture is not a gender-neutral field, and I am interested in contributing to the discussions in alternative agriculture today about the experiences of women farmers. Importantly, however, I am also seeking to privilege the reflexivity of my informants by not simply addressing how femininity interacts with women farmers' work. Rather, the paper represents the ways in which women farmers consciously understand their gender's interaction with their work, including the areas in which they deny its influence. In presenting women farmers' opinions on their gender's influence over two distinct areas of their work, this paper emphasizes the specific subjectivities of its informants by focusing on how the women farmers see themselves as alternately participating in, reproducing, and denying gendered traits.

This paper examines the different ways women farmers understand the relationship between their gender and their (a) general farming perspective, and (b) specific approach to sustainability. Disentangling "sustainability" from "general farming perspective" in alternative agriculture is delicate, but I believe instrumental in analyzing women's understandings of how their gender relates to their work. For the purposes of this paper, I use "general farming perspective" to refer to the underlying motivations, values, goals, and advantages women farmers see themselves bringing to their work. "Sustainability" refers primarily to the methods farmers employ to conserve their land and its natural resources, e.g., deciding not to use synthetic chemicals, buying seeds that are not genetically modified, or diversifying the farm operation.

\section{Methods}

The data presented in this paper were collected during a 10 -week ethnographic study conducted over the summer of 2008. After receiving approval from Grinnell College's Institutional Review Board, I met with the executive director of an Iowa-based nonprofit organization, the Women, Food and Agriculture Network (WFAN). The director explained the issues she saw as most pressing to women farmers in the Midwest, and provided names of two women farmers. After my interviews with them, these women recommended other women farmers they knew, thus creating a snowball sample. Through informal networking and contacting farmers through the Grinnell-area local foods network, I eventually interviewed 13 women. This paper focuses on the 11 women of this group who are small-scale farmers and consider themselves part of the Iowa local foods movement. All informants are white. At the time of the interviews, the women's ages ranged from 25 to 59 years (mode and mean 47). For 10 of the 11 interviews, after initial contact via email or phone, I drove to the farm to meet the farmer and conduct an in-person interview. I conducted one 
interview via phone due to scheduling. Interviews started with a tour of the farm and informal conversation, followed by a more formal interview comprising approximately 25 questions. The farm tour was useful for establishing rapport and tailoring some questions to the specific farm operation. Questions covered basic biographical information as well as farmers' opinions of the local food and organic food movements, their original motivations to start farming, the relationships between ethics, spirituality, and farming, and the roles of informal and formal communities for women in agriculture. This paper focuses on women's responses to the questions: "Do you think being a woman gives you a different perspective on farming?" "Do you think being a woman gives you any advantages in farming?" "Do you think being a woman gives you a different perspective on sustainability?" and "Has being a woman affected your farming practices?" I digitally recorded and later transcribed all interviews in outline form; including the farm tour, interviews ranged from an hour and fifteen minutes to two and a half hours. Ten of the farmers sold to customers directly through local farmers' markets or through a Community Supported Agriculture (CSA) system, and one, in her first season when I talked with her, intended to begin selling to customers as soon as possible. Ten women grew a variety of produce and vegetables on land ranging from half an acre to 80 acres ( 0.5 to 32.4 ha). One woman raised dairy goats.

\section{Results}

Of the 11 women in the study, eight felt that their gender influenced their farming perspective in general. Two women thought their gender also influenced their perspective on sustainability, six did not think there was a connection between their gender and sustainability, and three felt ambivalently. No informant thought that her gender exclusively influenced her farm's sustainability. Among the women who felt there was a connection between their gender and general farming perspective, the most frequently mentioned feminine stereotypes were the ideas that women are more nurturing, that women are inherently more connected to the earth, and that women are better problem solvers than men.
Gender's Influence on General Farming Perspective When asked if their gender influenced their farming perspective in a general sense, informants most frequently referred to the ideas that women are more concerned with health issues, more nurturing, and more innately attuned to the earth and living things, all of which were often related back to motherhood. Referenced slightly less often were women's communication and problem-solving skills. One woman who farms full-time to supply her 150 CSA customers said:

Certainly there tend to be more nurturing issues, and that's why I think there might be, why there tend to be more women doing this growing of food than men, or more women interested in it at least, because of the nurturing tendencies. [Women] tend to be the caretakers, tend to be the ones that feed the rest of the family.

The belief that women are inherently more nurturing, and therefore better suited to farm, was not unique to women employed in horticulture. The informant who raises goats also felt strongly that women's natural tendency towards nurturing gave her advantages in farming:

I do think women are much better livestock managers, because we're much more sensitive to changes in the animals, we're much more observant. That sounds very sexist in the opposite way, but it's just true. It's the nurturing side of us, if someone's hanging back and not behaving typically, that's usually your first sign of illness. And I can pick those things up quickly, whereas a lot of men wouldn't even notice it or pay attention to it until [the animal is] sick and down.

When asked if being a woman gave her a different perspective on farming, another informant who grows vegetables to sell at farmers' markets answered:

I think it does. I think it gives you more of a connection with the earth and I think it 
gives you more of a connection with the food. A lot of the guys I see who are vendors growing and selling, I don't see that connection and the love of the stuff like the women....I think it's just the woman thing.

Many farmers were comfortable applying these ideas to their own lives even as they were simultaneously conscious of the ideas' stereotypical nature. For example, when asked if her gender gave her a different perspective on farming, one farmer told me:

We're aware of gender roles and sexism, but we clearly fall into these categories where the nutrition is my responsibility, and [my husband's] responsibility is our financial security. He cares a lot about that....It's something that's hardwired. For women, that hardwiring nurturing thing....I think in general, that nutrition thing is really important, that healthy food, and I think for a lot of women that translates to healthy land.

Another farmer replied:

I really hate to genderfy it...."Women are more nurturing," I kind of resist those statements.... On the other hand, women do have babies, women do take care of children, and women do put food on the table, the majority of women do. And in the world, women are the majority of farmers....It's always been a woman's job to put food on the table, and if there's not enough food, she doesn't eat.

Eight of my informants had children; of these, seven connected the ideas of mothering and farming, either through anecdotes of the relationships between their farms and families, or on a more conceptual level. One woman went so far as to say:

I always tell people I'm hooked up with this umbilical cord to the farm during the growing season. But you do...get attached to it, it's like your baby, you're taking care of it, you're trying to improve it, you want it to be healthy and to grow, and, in turn, feed you back in a healthy matter....I suppose it's the nurturing aspect. You put into it and it gives back.

The idea that women are naturally more "connected" to the earth, and therefore better suited to take care of it and grow on it, hints at one of the underlying ideas behind many women's answers: that women tend the earth better because it itself is a feminine being. "I like to think it helps me, the whole 'earth mother' concept," one woman told me. Similar themes were echoed by two other informants:

Well, I think if I'm friendly to the land, it's going to be friendly to me and give me back what I need. I'm not going to abuse it, bury stuff in it, put stuff in it that it doesn't like. I kind of think of the earth as my body. Would I put that on my body, would I do that to myself? The earth doesn't really like it either.

The whole treatment of the land, that's what ecofeminism is about, the rape and pillage of this living entity, and that's why women I think are so closely attached to it.... How we treat animals, how we treat people all stems from how we treat the earth. And we don't treat her very well. And when we don't treat her very well, we're not going to treat each other very well. To me, it's a very big ethical and moral question.

The concepts of nurturing, health, and a more intuitive relationship with the earth are feminine stereotypes that some women farmers are willing to engage and even cite as influential to their way of viewing the land.

In a different vein, several other informants pointed to a belief that women are naturally better communicators and problem solvers, which gives them a different perspective, and distinct advantages, in farming. One informant, who did not 
otherwise credit her gender with much influence over her farming, thought that in certain situations women farmers without an agricultural background might be more creative problem solvers. She explained,

I really think that women look at problems in a different way and try to figure out perhaps a more elegant solution.... You can take brute force and hook a machine up to the tractor, or you can use a lever. And if you don't have the brute force, then right from the start you start thinking, 'How can I do this job by using physics as my friend?' I think women approach problems from more out-there starting places because we don't have the strength or the experience to know, necessarily, the typical way to solve the problem.

When asked about advantages women have in farming, other informants said:

In this style of farming, it requires a lot of multitasking skills, and a lot of communication skills in the farming that we are involved in, and women have a lot of ability and a lot of skill in that, and I think in more conventional agriculture I'm sure that women have a lot to offer there....I think women have a lot of advantage.

I think there are several things that women have as advantages over men, and it has all to do with society, the way we're raised...Y You have to see this whole picture of things and then make choices about what you're going to do. [Men] head down one path and stay on that path.

The themes emphasized by my informants echo and reaffirm those indicated by previous studies on women farmers (Chiappe \& Flora, 1998; Trauger et al., 2010). Like their counterparts in Minnesota and Pennsylvania, the Iowan women farmers whom I interviewed stressed quality family life, health, and nurturance as valued elements of their farms; additionally, several of my informants indicated women's adeptness at problem solving and multitasking. However, the women with whom I spoke explicitly connected their gender to these issues within their general farming perspectives. They articulated relationships between these ideas and their own gender identities, and frequently commented on the stereotypically gendered nature of the very issues they mentioned.

\section{Gender's Influence on Approach to Sustainability} While many farmers were comfortable aligning themselves with positive popular beliefs about women in a general sense, when asked if their gender gave them a different perspective on the more specific issue of farm sustainability, significantly fewer (only two out of 11) felt that it was an important factor. Women were more likely to credit their education or colleagues with influencing their views on sustainability. One farmer who holds a degree in agronomy and studied soil conservation unambiguously answered:

My approach to sustainability comes from my education, because I have so much ecology and systems thinking in my education that I see sustainability as a component of functionality. If you want the farm to work, you've got to be sustainable. I would say that's because of my education, and not because of my gender.

Another farmer with degrees in chemistry and horticulture simply replied, "I don't see [sustainability] as being a gender issue." Networking and collaborating with other farmers in the alternative agriculture movement, especially through the organization Practical Farmers of Iowa (PFI), were frequently mentioned as influencing farming methods as well.

I would say that being active in PFI, there are a lot of great farmers out there, male and female, and I've learned a lot from all of them. I could never say it's been more women.... Where I'm coming from that hasn't been my experience. My dad was totally into sustainability as a farmer, so I came from a background of viewing the 
world that way. So from my perspective, no.

One farmer thought that while on a larger scale women might be more dedicated to conservation and sustainable practices, in her own experiences in the alternative agriculture communities that division blurred:

I don't know if I would say a distinctive difference between women and men.... When you asked me that question I was at first thinking in terms of my sustainable agriculture network of people and that's where I feel like that division is not as sharp. But if I looked in a broader context, I would say, yeah I think there's maybe a stronger distinct boundary [between men's and women's approaches to sustainability].

The farmers who did indicate that their gender influenced their approach to sustainability were also generally less willing to make clear divisions between the genders or implicate men as being "less sustainable." When asked if her gender influenced her perspective on sustainability, one informant answered:

Probably....I do think [women] value the earth more, and that has been one of my big issues....I guess I can't honestly say, but I suppose because I'm a woman I don't have the same bias towards conventional farming, but not [having a background in farming], that could be either way, it might not be being a woman.

While some women saw varying degrees of connection between their gender and their farm's sustainability practices, most informants were more inclined to credit their social networks in the alternative agriculture movement or their education as primarily influential. Possible secondary effects of gender on a farmer's perspective on sustainability (e.g., gender's relationship to networking) are beyond the scope of this study.

\section{Discussion}

The women I interviewed for this study belong to the increasing population of women farmers who are consciously articulating the relationships between their gender and their farm work. A majority of them felt that their gender influenced their general farming perspective or gave them distinct advantages. This paper highlights how women farmers use their gender to frame and contextualize some of their farming choices. For the majority of my informants, the fact that they are women actively shapes how they understand themselves as farmers in a general sense. By voicing such concepts and claiming them as their own, women reproduce these gendered traits and promote them in agricultural circles, influencing not just their own farms, but also the way other people view women's agricultural work. References to women's superior problem-solving or communication skills are clearly distinct from references to women being inherently nurturing or tied to the earth. However, they are similar in that they are considered generally positive facets of womanhood and, notably, both these attitudes are embraced by some women farmers when describing ways their gender influences their relationship to the land and their perspective on farming. Put another way, none of these informants talked about women being too delicate to drive a tiller, too moody to manage crop rotations, too catty to engage market customers, or any other negative feminine stereotypes. Women farmers selectively reproduce some feminine stereotypes by accepting positive cultural concepts associated with women, then using these to frame their own experiences and explain their work to others. These stereotypes, in turn, can become more firmly rooted in the cultural meaning of "woman" and could potentially shape how a woman understands her relationship to agriculture.

My informants felt quite differently about their gender's ability to inform their work when questioned about the specific topic of sustainability; the majority did not feel that their gender was an important factor. I believe this is related to sustainability's centrality within the alternative agriculture movement, with which all of my informants identified. Because the alternative agriculture movement views the dominant, conventional model of farm- 
ing in America as entrenched in wasteful and unsustainable practices, alternative farmers often consider the pursuit of sustainable food growing methods the most important issue in farming (see Bell, 2004; Hassanein, 1999; Lyson, 2004; NorbergHodge, Merrifield, \& Gorelick, 2002). While people may disagree over the specifics of how to be sustainable or what sustainable practices entail, the pursuit of sustainability unites alternative farmers. Beus and Dunlap's (1990) classic alternative agriculture paradigm comprises decentralization, independence, community, harmony with nature, diversity, and restraint. Sustainability underlies or supports all elements of the alternative paradigm, in addition to providing a clear, definable goal behind which alternative farmers can unite. Pursuing and valuing sustainability is a crucial element of one's identity as a nonconventional farmer. This centrality to the alternative agriculture movement perhaps explains why the majority of informants did not see their approach to sustainability as tied to their gender. There is a limit to the extent to which some women are willing to attribute their actions to their gender, especially when other factors in which they may be more actively invested are present. All farmers in this community pursue sustainability, and the identities of women participating in this movement are strongly shaped by the movement's goals and key issues. In refusing to connect their farm's sustainability to their gender, these women are identifying with the progressive, alternative agriculture movement more than they are with conventional ideas of femininity.

\section{Conclusion}

Concurrent with the increasing numbers of women farmers in the United States, the last decade has seen a marked rise in organizations and programs targeted specifically at women in agriculture. These organizations are vital in that they provide mentoring, networking, education and camaraderie for women who sometimes find more traditional sources of agricultural community lacking. This study found that women farmers place a high value on sustainable practices but do not see their preference for such practices as connected to their gender as other aspects of their farming. These findings may prove valuable to women's farm organizations as they design and implement programming. Since these organizations seek to create spaces specifically for women farmers, and, importantly, since mixed-gender farm groups are also growing and often focus on sustainable agriculture practices, the women-specific groups may find it efficient to focus their resources on addressing the issues women farmers consider related to their gender. Such programming could focus on topics including the scarcity of farm machinery and tools sized for women's bodies, combating the ongoing stereotype that women on farms are not "real farmers," or connecting the values of contemporary women farmers to the global and historical feminine roles as food providers. A majority of my informants stressed such topics as deeply important to them, and they also made explicit connections between these ideas, their approach to farming, and their gender. As connections between an informant's gender and her approach to sustainability were less common, developing and promoting sustainable farming practices may best utilize the resources of mixedgender alternative agriculture groups.

Further research is needed in pursuing questions of geography: would women farming in alternative agriculture circles in other parts of the country share Iowan women farmers' opinions on gender's influence? What differences would surface among women farmers in other regions, such as an organic farmer in California? Some important work has already been done on the relationship between masculinity and male farmers' work (Brandth, 1995; Ferrell, 2012; Laoire, 2002; Peter et al., 2006). However, further questions remain on male farmers' gender identities in the changing field of agriculture, as do questions on gendered relationships between farm couples. Finally, as all but two informants for this study were over 40 , future studies could focus on the views of the younger generation of women farmers who grew up after the feminist movement and may use significantly different lenses for understanding their gender identities.

\section{Acknowledgments}

I would like to thank all of the farmers who participated in this study and generously shared their experiences 
and insights. Jon Andelson, Brigittine French, and the Grinnell College Department of Anthropology provided invaluable mentorship and support of the project in all its stages. I am grateful to Leigh Adcock of the Women, Food and Agriculture Network for her thoughtful comments on a draft of this manuscript. I would also like to thank the anonymous reviewers for their valuable comments during the revision process. Grinnell College provided funding to conduct the research.

\section{References}

Allen, P., \& Sachs, C. (2007). Women and food chains: The gendered politics of food. International Journal of Sociology of Food and Agriculture, 15(1), 1-23.

Barbercheck, M., Brasier, K., Kiernan, N., Sachs, C., Trauger, A., Findeis, J., Stone, A., \& Moist, L. (2009). Meeting the extension needs of women farmers: A perspective from Pennsylvania. Journal of Extension, 47(3), article 3FEA8. http://www.joe.org/joe/2009june/a8.php

Bauman, C. (2012). Making changes and coming full circle: $A$ look at how women farmers in Oregon and Washington define their own identities, realities, and contributions (Master's thesis). SIT Graduate Institute, Brattleboro, Vermont. Retrieved from the Capstone Collection: http://digitalcollections.sit.edu/capstones/2495

Bell, M. M. (2004). Farming for us all: Practical agriculture \& the cultivation of sustainability. University Park, Pennsylvania: Pennsylvania State University Press.

Beus, C. E., \& Dunlap, R. E. (1990). Conventional versus alternative agriculture: The paradigmatic roots of the debate. Rural Sociology, 55(4), 590-616. http://dx.doi.org/10.1111/j.15490831.1990.tb00699.x

Brandth, B. (1994). Changing femininity: The social construction of women farmers in Norway.

Sociologia Ruralis, 34(2-3), 127-149.

http://dx.doi.org/10.1111/j.14679523.1994.tb00805.x

Brandth, B. (1995). Rural masculinity in transition: Gender images in tractor advertisements. Journal of Rural Studies, 11(2), 123-133. http://dx.doi.org/10.1016/0743-0167(95)00007-A

Brandth, B., \& Haugen, M. S. (1997). Rural women, feminism and the politics of identity. Sociologia Ruralis, 37(3), 325-344. http://dx.doi.org/ 10.1111/j.1467-9523.1997.tb00054.x
Chiappe, M. B., \& Flora, C. B. (1998). Gendered elements of the alternative agriculture paradigm. Rural Sociology, 63(3), 372-393. http://dx.doi.org/10.1111/j.15490831.1998.tb00684.x

Ferrell, A. K. (2012). Doing masculinity: Gendered challenges to replacing burley tobacco in central Kentucky. Agriculture and Human Values, 29(2), 137 149. http://dx.doi.org/10.1007/s10460-011-9330-1

Hassanein, N. (1999). Changing the way America farms: Knowledge and community in the sustainable agriculture movement. Lincoln, Nebraska: University of Nebraska Press.

Jellison, K. (1993). Entitled to power: Farm women and technology, 1913-1963. Chapel Hill, North Carolina: University of North Carolina Press.

Laoire, C. N. (2002). Young farmers, masculinities and change in rural Ireland. Irish Geography, 35(1), 16-27. http://dx.doi.org/10.1080/00750770209555790

Lyson, T. (2004). Civic agriculture: Reconnecting farm, food, and community. Medford, Massachusetts: Tufts University Press.

Norberg-Hodge, H., Merrifield, T., \& Gorelick, S. (2002). Bringing the food economy home: Local alternatives to global agribusiness. Bloomfield, Connecticut: Kumarian Press.

Peter, G., Bell, M. M., Jarnagin, S., \& Bauer, D. (2006). Cultivating dialogue: Sustainable agriculture and masculinities. In H. Campbell, M. M. Bell, \& M. Finney (Eds.), Country boys: Masculinity and rural life (pp. 23-46). University Park, Pennsylvania: Pennsylvania State University Press.

Pini, B. (2005). Farm women: Driving tractors and negotiating gender. International Journal of Sociology of Agriculture and Food, 13(1), 1-18.

Sachs, C. (1983). The invisible farmers: Women in agricultural production. Totowa, New Jersey: Rowman \& Allanheld.

Trauger, A. (2004). "Because they can do the work": Women farmers in sustainable agriculture in Pennsylvania, USA. Gender, Place \& Culture: A Journal of Feminist Geography, 11(2), 289-307. http://dx.doi.org/10.1080/0966369042000218491

Trauger, A., Sachs, C., Barbercheck, M., Brasier, K., \& Kiernan, N. E. (2010). "Our market is our community": Women farmers and civic agriculture in Pennsylvania, USA. Agriculture and Human Values, 27(1), 43-55. http://dx.doi.org/10.1007/s10460008-9190-5 
Trauger, A., Sachs, C., Barbercheck, M., Kiernan, N. E., Brasier, K., \& Findeis, J. (2008). Agricultural education: Gender identity and knowledge exchange. Journal of Rural Studies, 24(4), 432-439. http://dx.doi.org/10.1016/j.jrurstud.2008.03.007

U.S. Department of Agriculture [USDA] National Agricultural Statistics Service. (n.d.). 2007 Census of
Agriculture: Women farmers. Retrieved from http://www.agcensus.usda.gov/Publications/2007 LOnline Highlights/Fact Sheets/Demographics/ women.pdf

Wardlow, H. (2006). Wayward women: Sexuality and agency in a New Guinea society. Berkeley, California: University of California Press. 